\title{
越流・浸透流作用時における被覆ブロックの 形状に関する水理模型実験
}

\author{
竹下 修平1・笠間 清伸 2 ・中川 康之 3 ・ \\ 善 功企 $4 \cdot$ 古川 全太郎 $5 \cdot$ 八尋 祐一 6 \\ 1 学生会員 九州大学大学院工学府建設システム工学専攻 \\ ( ( 814-0395 福岡県福岡市西区元岡 744) \\ E-mail:syu060101@gmail.com \\ 2 正会員 九州大学大学院工学研究院社会基盤部門（T814-0395 福岡県福岡市西区元岡 744） \\ E-mail: kasama@civil.kyushu-u.ac.jp \\ 3 正会員 九州大学大学院工学研究院海域港湾環境防災共同研究部門 \\ ( ( 814-0395 福岡県福岡市西区元岡 744) \\ 4 フェロー会員 九州大学大学院工学研究院海域港湾環境防災共同研究部門 \\ ( \%814-0395 福岡県福岡市西区元岡 744) \\ 5 正会員 九州大学大学院工学研究院社会基盤部門（干814-0395 福岡県福岡市西区元岡 744） \\ 6 正会員 九州大学大学院工学府建設システム工学専攻（†814-0395 福岡県福岡市西区元岡 744）
}

\begin{abstract}
本論文では，防波堤の耐津波対策の一つである，被覆ブロックに着目した。そこで，我々の研究グル 一プが提案する，浸透流を考慮した被覆ブロックの安定重量算出式を用いて適当な形状を導き，水理模 型実験によりその有効性を検討した．以下にその結果をまとめる．1）間隙のある被覆ブロックは浸透流 による被害が抑えられた。 2) 脚の効果により, 浸透流による滑り落ちるような移動が抑えられた。 3)本 方法により算出された重量のブロックでは設定外力以下の条件で移動が生じる場合があり, 算出方法に 改良の余地がある.4) 被覆ブロックの水位差による浸透流に対する安全率を求めたところ, 実験結果を 適切に評価できることがわかった。
\end{abstract}

Key Words : reinforcement block, seepage flow, overflow, breakwater, seepage failure

\section{1. はじめに}

平成 23 年東北地方太平洋沖地震による津波により, 甚 大な被害が生じた．津波による防波堤の被災要因は 3つ に大別され，防波堤の前面と背面との水位差と津波波力 によるケーソンへの水平力，越流と捨石マウンド内の浸 透力による捨石マウンドの洗掘と抜け出し, 捨石マウン ド内の浸透力による捨石マウンドの支持力低下が挙げら れる. なかでも捨石マウンドの洗掘・抜け出しを防ぐ対 策として被覆ブロックの設置がある．被覆ブロックにつ いては盛んに研究が行われている 1,2,3). そこで我々の研 究グループ 4)が提案する浸透流を考慮した安定重量の算 出式を用いて被覆ブロックの適当な形状を導き，水理模 型実験によりその有效性を検討した。

\section{2. 最適な形状の推定}

式(1)に浸透流を考慮した安定重量の算出式を示す.

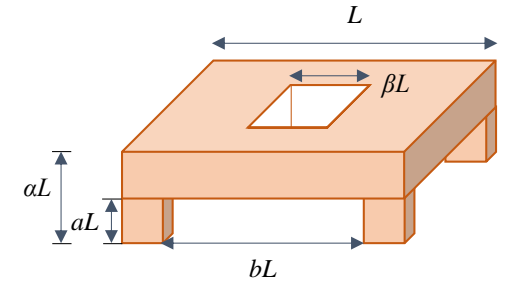

図-1＼cjkstart被覆ブロックの概念図

$$
W_{s}=\frac{k_{a}^{3} \gamma_{s} C_{D}{ }^{3} u^{6}}{8 k_{v}{ }^{2} g^{3}\left[\left\{f_{r}\left(\cos \theta-\frac{1+e}{G_{S}-1} i\right)-\sin \theta\right\}\left(G_{S}-1\right)\right]^{3}}
$$

ここで， $k_{v}$ : 体積係数, $k_{a}$ : 面積係数, $\gamma_{s}$ : 被覆ブロック の単位体積重量 $\left[\mathrm{kN} / \mathrm{m}^{3}\right], C_{D}$ : 抗力係数, $f_{r}$ : 摩擦係数, $\theta$ : マウンド角度 $[\mathrm{rad}], G_{s}$ : 比重, $e$ : 間隙比, $i$ : 動水勾配, $u$ : マウンド被覆ブロックへの衝突流速 $\left[\mathrm{m} / \mathrm{s}^{2}\right]$ である。こ のうち, 被覆ブロックの形状を表すパラメータは $k v, k a$, $e$ である. $k_{v} \cdot k_{a}$ は被覆ブロックの体積 $V\left[\mathrm{~m}^{3}\right] \cdot$ 投影面積 $A\left[\mathrm{~m}^{2}\right]$ を表す際に用い, 次のように表される. 


$$
V=k_{v} q^{3}, \quad A=k_{a} q^{2}
$$

ここで, $q$ は被覆ブロックの代表長さ $[\mathrm{m}]$ である.

本研究では模型被覆ブロックの作りやすさを考慮し, 図-1に表される被覆ブロックについて検討した．代表長 さ $q$ を $L$ とし, ブロックの高さを $\alpha L$, 空隙の長さを $\beta L$, 脚の高さを $\mathrm{a} L$, 脚の間隔を $b L$ として表し, 被覆ブロッ クの形状を表すパラメータである $k_{v}, k_{a}, e$ を計算する. 式(2)及び実際の体積計算

$$
\begin{aligned}
V=\left(\alpha-2 a b+a b^{2}-\beta^{2}(\alpha-a)\right) L^{3} \text { から } \\
k_{v}=\alpha-2 a b+a b^{2}-\beta^{2}(\alpha-a)
\end{aligned}
$$

また，式(3)及び実際の面積計算 $A=(\alpha-a b) L^{2}$ から，

$$
k_{a}=\alpha-a b
$$

間隙比 $e$ はブロックの体積と間隙の比で表されるため, 次式(6)となる.

$$
e=\frac{2 a b-a b^{2}+\beta^{2}(\alpha-a)}{\alpha-2 a b+a b^{2}-\beta^{2}(\alpha-a)}
$$

式(4)，(5)，(6)から，パラメータ $\alpha \cdot \beta \cdot a \cdot b$ を変化させ $\tau k_{v} \cdot k_{a} \cdot e$ を計算し,式(1)加最小となる安定重量 $W_{s}[\mathrm{kN}]$ を算出した。ささらに次式(7)から最小となる安定重量にお ける代表長さ $L$ を求めた。

$$
V=k_{v} L^{3}=\frac{W_{s}}{\gamma_{s}} \text { より } \quad L=\left(\frac{W_{s}}{k_{v} \gamma_{s}}\right)^{1 / 3}
$$

\section{3. 水理模型実験の概要}

本実験装置は岩手県釜石湾口防波堤南堤をモデルとし て，1/100 の尺度となるよう作成した. 図-2 に実験装置の 概略と計測器の配置図を示寸。水圧計は図のように設置 し，実験開始時の水位 (マウンド天端からの高さ $25 \mathrm{~mm}$ ) において，初期值が 0 となるように設定した．図の右側 が港外側，左側が港内側となるようにした．また，流速 計はケーソン上部の港内側の端に設置した．水位を設定 するために，両側にスライド式プラスチック板のゲート を設置した。これを制御し，港内側と港外側の水位を操 作した.

また，実験に用いた砕石等の条件を表-1 に示寸，津波 を模擬するために，港内側の設定水位を一定に保ち，港 外側のゲートの高さを $1 \mathrm{~mm} / \mathrm{s}$ の速さで上昇させること で港外側の水位のみを増加させ，水位差を発生させた。 模型被覆ブロックは図-3 に示す Case1，Case2(穴あき), Case3(穴あき+脚つき)を使用した. Case3 の代表長さ $L$ を

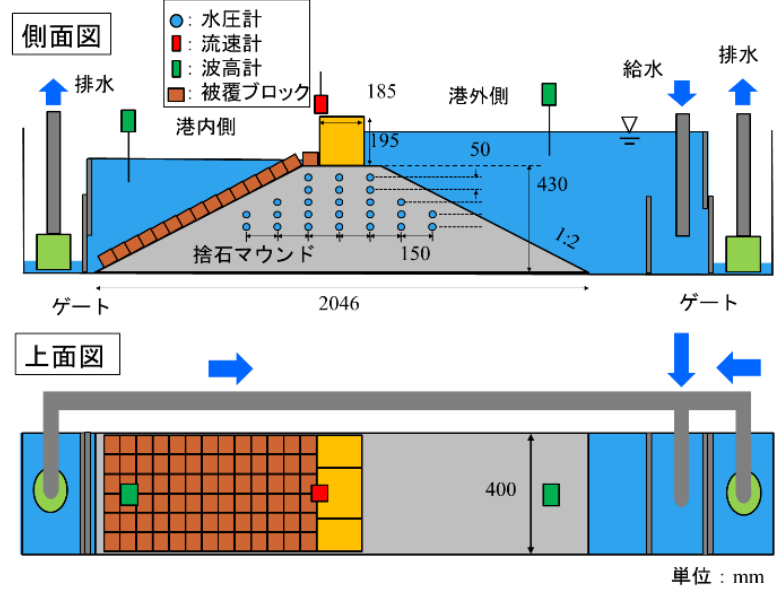

図-2＼cjkstart計測器の配置および実験装置の概要図

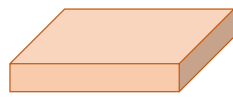

a) Case 1

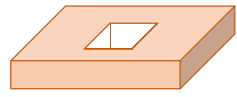

\begin{tabular}{|c|c|c|}
\hline モデル & 釜石湾口防波 & （縮尺 1/100） \\
\hline \multirow[t]{3}{*}{$\begin{array}{c}\text { 捨石 } \\
\text { マウンド }\end{array}$} & 寸法 & $\begin{array}{c}\text { 上底 } 326 \mathrm{~mm} \\
\text { 下底 } 2046 \mathrm{~mm} \\
\text { 高さ } 430 \mathrm{~mm} \\
\text { 法面の勾配 } 1: 2\end{array}$ \\
\hline & 捨石の粒径 & $2 \mathrm{~mm} \sim 26.5 \mathrm{~mm}$ \\
\hline & 飽和密度 & $1.90 \mathrm{~g} / \mathrm{cm}^{3}$ \\
\hline 設定水位差 & \multicolumn{2}{|c|}{$0 \mathrm{~mm} \sim 135 \mathrm{~mm}$} \\
\hline 港内側水位 & \multicolumn{2}{|c|}{25 mm（マウンド天端の高さを基淮） } \\
\hline
\end{tabular}

b) Case2

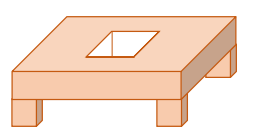

c) Case3 図-3＼cjkstart被覆ブロックの形状

表-1 実験条件

表-2 被覆ブロックの諸元

\begin{tabular}{|c|c|c|c|}
\hline 模型の種類 & Case1 & Case2 & Case3 \\
\hline 重量 $[\mathrm{N}]$ & 0.45 & 0.42 & 0.47 \\
\hline 代表長さ $L[\mathrm{~mm}]$ & \multicolumn{3}{|c|}{46} \\
\hline$\alpha$ & 0.2 & 0.2 & 0.4 \\
\hline$\beta$ & 0 & 0.33 & 0.33 \\
\hline$a$ & 0 & 0 & 0.2 \\
\hline$b$ & 0 & 0 & 0.6 \\
\hline 間隙比 $e$ & 0 & 0.12 & 0.90 \\
\hline 摩擦係数 $f_{r}$ & \multicolumn{4}{|c|}{0.680} & 0.821 \\
\hline
\end{tabular}


計算により求め，さらに浸透力を低減させることを目的 とした中央部の穴と，マウンドとのかみ合わせ及び摩擦 力の増加を目的とした脚の効果を調べるため, Case1 と Case2 との比較を行った. 各ケースで用いたブロックの 諸元を表-2 に示す. Case3 の安定重量 $W_{\mathrm{s}}[\mathrm{N}]$ の算出に用い たパラメータについて $C_{D}$ は $0.1 ， \gamma_{\mathrm{s}}$ は $22.54 \mathrm{kN} / \mathrm{m} 3 ， G_{\mathrm{s}}$ は 2.3 とした. また動水勾配 $i$ は水位差 $135 \mathrm{~mm}$ における值 を用い, 0.423 とした. なお再現性を確認寸るため, 実験 は最低 2 回行った。

\section{4. 実験結果}

図-4にゲートの高さを入力して発生させた設定水位と, 波高計で測定した水位および流速計で測定した越流水の 流速を示す．実験時には港内側設定水位よりも，実際の 水位の方が高くなることがわかる．これは図-2 に示寸港 内側のポンプによる水の排水が追いつかないためである. 最終的に水位差 $135 \mathrm{~mm}$ まで計測した。 また，水位差 $125 \mathrm{~mm}$ あたりで越流が生じ始めるため, ケーソンの直上 に設置した流速計の值が増加し, 最終的には $50 \mathrm{~cm} / \mathrm{s}$ 程度 まで越流水の流速が増加した。

図-5にマウンド内の水圧計から測定した過剩間隙水圧 分布を示寸. $h_{t}(\%)$ は捨石マウンド内における過剩水圧の 割合を表す．捨石マウンド内の間隙水圧は港外側から港 内側に向かって水平方向に滑らかに遷移することがわか る.これに対して鉛直方向への大きな変化は見られない. これらのことから, 港外・港内側で水位差が発生する状 態において, 間隙水圧の変化は水平方向に卓越している といえる.

図-6に図-5の過剩間隙水圧分布から計算した水平方向 の動水勾配 $i_{\mathrm{x}}$ のコンター図を示寸： $i_{x}$ は水平方向の動水 勾配を表し, 図の右から左への水平方向の流れを正とし た. 発生した水位差が最大となる時，マウンド全体で動 水勾配分布が大きくなり，特にケーソン直下で著しく大 きくなった．これは，ケーソン直下では浸透流の経路が 最も短くなるため, 動水勾配が大きくなると考えられる. このことに対応して，防波堤の被災要因の一つであるケ ーソン直下でのマウンドの支持力低下を確認した.

図-7に，図-5 の全水頭分布から計算した鉛直方向の動水 勾配 $i_{y}$ のコンター図を示寸. 同図では鉛直方向上向きの 流れを正としており，青色で示された部分では鉛直下向 きの，赤色で示された部分では鉛直上向きの浸透流がそ れぞれ発生していることを示している. 水位差が最大と なる時には，港内側の捨石マウンド内の鉛直方向の動水 勾配が大きくなることがわかる. 港内側の捨石マウンド， 特に法肩付近では，動水勾配に起因して鉛直上方向に浸 透流が発生しており, 被覆ブロックに浸透力が作用して いることがわかる。

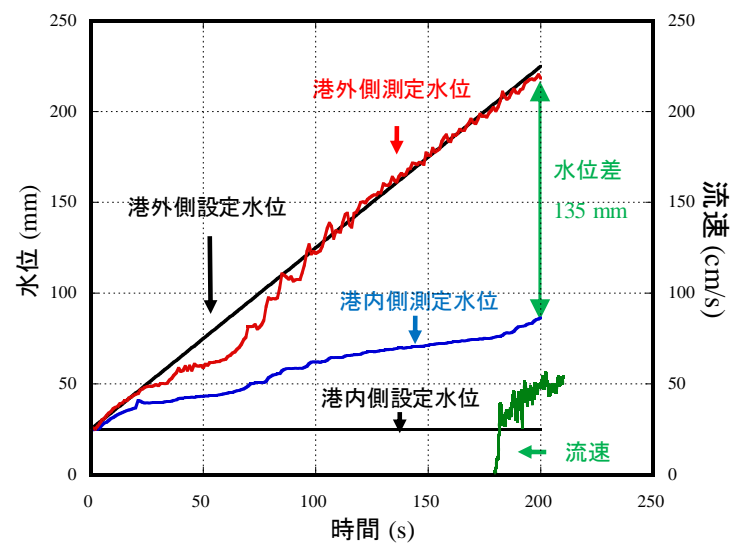

図-4 設定水位と測定水位および流速

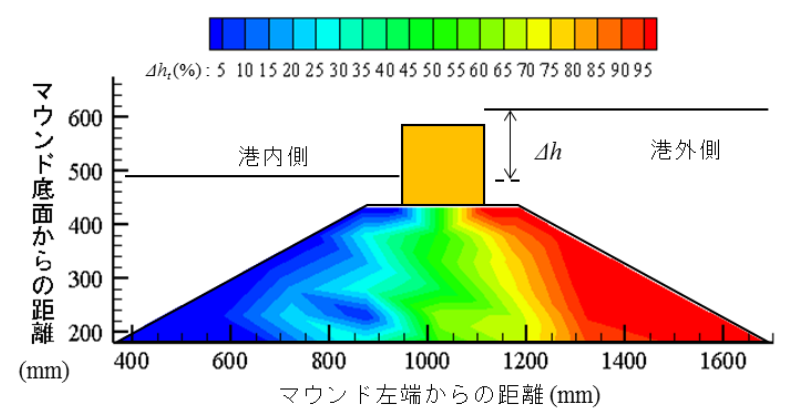

図-5 過㮃間隙水圧分布 $(\Delta h=135 \mathrm{~mm})$

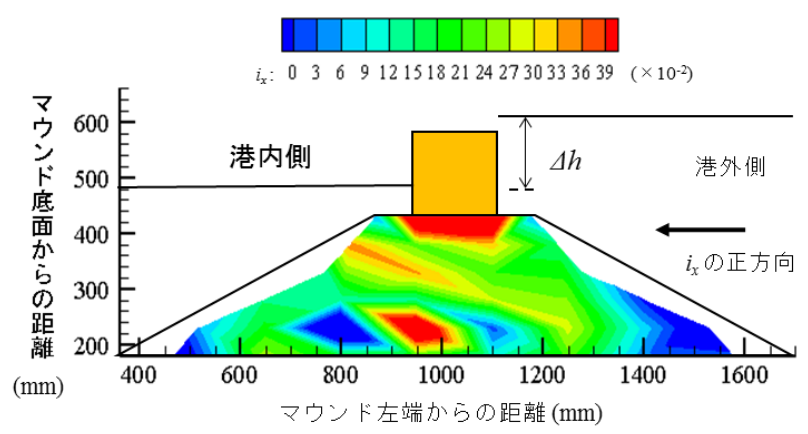

図-6 水平動水勾配分布 $(\Delta h=135 \mathrm{~mm})$

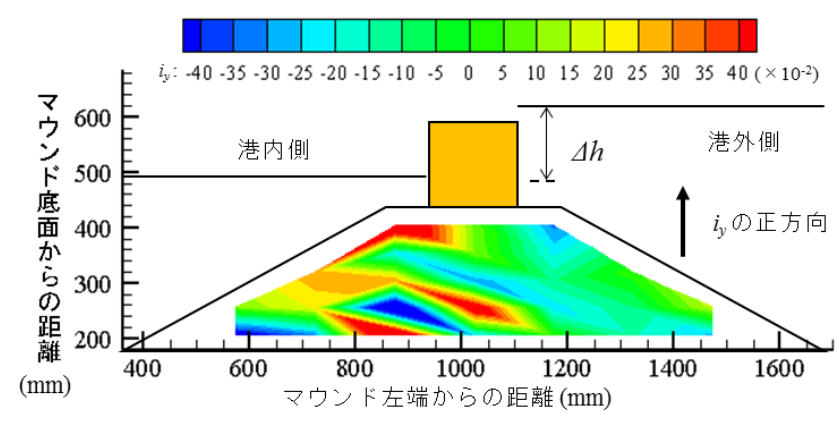

図-7 鉛直動水勾配分布 $(\Delta h=135 \mathrm{~mm})$ 
写真-1,2 に Case1 と Case3 の実験後の被覆ブロックの 様子を示す. Case1 において, 越流が発生した水位差 125 $\mathrm{mm}$ 程度となる以前から法面上の被覆ブロックがすべり 落ちるように移動する現象 (本文では表層すべりとする) が見られた. これは水位差による浸透力が被覆ブロック に対して上向きにはたらき，被覆ブロックとマウンド間 の摩擦抵抗が軽減されたためと考えられる. 一方, Case3 では越流前の浸透力による移動は起こらなかったが，越 流後水位差 $130 \mathrm{~mm}$ を超えると被害が発生した.

図-8に, 水位差と被覆ブロックの被害率 $D$ の関係を示 す. 直線は目視で確認された越流時の水位差 (125mm) を示す．被害率は被覆ブロックの被災の程度を表し，以 下の式(8)で決定した。 ここで，被災した被覆ブロックと は，最初の位置から約 1 個分移動したものと定義した.

$$
D=\frac{\text { 被災した被覆ブロック }}{\text { 被覆ブロックの総数 }}[\%]
$$

脚のついていない Case1 と Case2 では，越流が発生す る以前に被害が発生した. Case1 と Case2 を比べると浸 透流を低減する間隙をもつ Case2 の方が浸透流での被害 は抑えられていた. 一方, 脚のついた Case3 では滑り落 ちるような移動は発生しなかった. Case3について, 水 位差が $130 \mathrm{~mm}$ 付近までは越流水による被害は抑えられ ていたが，130mm を超えると全体的に被災した. Case3 について水位差 $135 \mathrm{~mm}$ での安定重量を算出し, 最適形 状として実験を行ったが，水位差 $130 \mathrm{~mm}$ 程度まで被害 は抑えられた。しかし，それ以上だと被害が発生したた め，算出方法に改良の必要がある.

\section{5. 浸透流に対する被覆ブロックの安定性評 価}

\section{（1）被覆ブロックに作用するカ}

水位差による浸透流作用時における被覆ブロックの安 定性を評価するため，図-9 に被覆ブロックに作用する外 力を示す.ひとつの被覆ブロックが受ける斜面法線方向 の浸透力は次式(9)で表される.

$$
F_{s e}=\gamma_{w} V(1+e) i
$$

また，被覆ブロックの摩擦抵抗力 $R$ は次式(10)で与えら れる.

$$
R=f_{r}\left\{W^{\prime} \cos \theta-\gamma_{w} V(1+e) i\right\}
$$

ここに, $F_{s e}$ : 浸透力 $[\mathrm{kN}], R$ : 摩擦抵抗力 $[\mathrm{kN}], W^{\prime}$ : 被覆 ブロックの水中重量 $[\mathrm{kN}], f_{r}$ : 被覆ブロックのかみ合わ せおよび摩擦による係数, $\gamma_{w}$ : 流体の単位体積重量, $V$ : 被覆ブロックの体積 $\left[\mathrm{m}^{3}\right], e$ : 被覆ブロックの間隙比, $i$ : 動水勾配である.

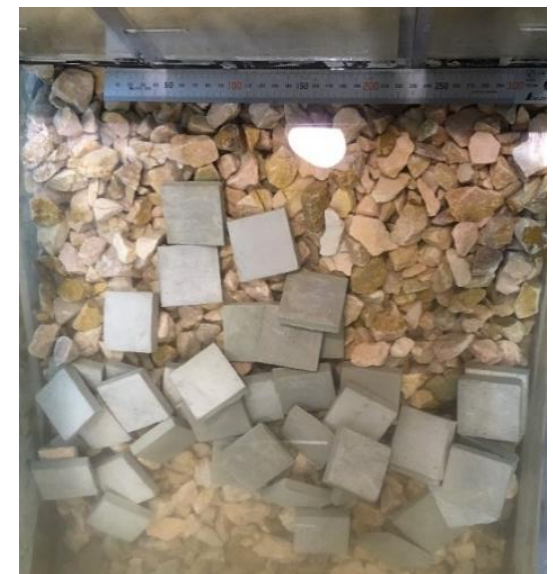

写真-1＼cjkstart実験後の被覆ブロックの様子(Case1)

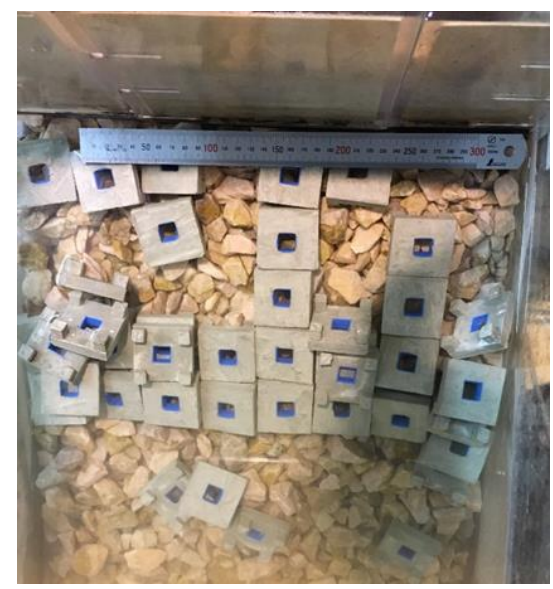

写真-2＼cjkstart実験後の被覆ブロックの様子(Case3)

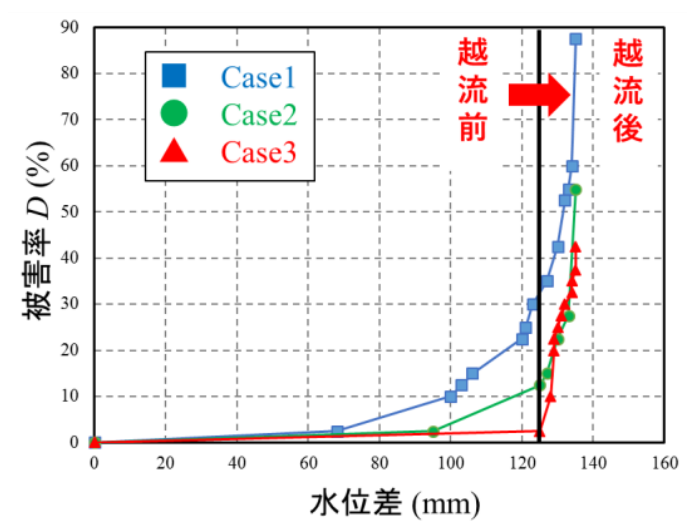

図-8 水位差と被害率の関係

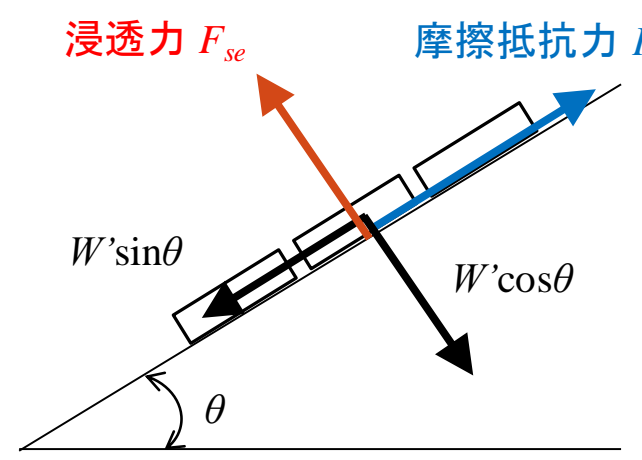

図-9＼cjkstart被覆ブロックに作用する外力の模式図 


\section{(2) 表層すべり}

被覆ブロックの自重による斜面方向の力が摩擦抵抗を 上回る $(R<W ' \sin \theta)$ ことによて，表層すべりが発生する 限界動水勾配 $i_{c}$ を計算したものが式(11)である ${ }^{4}$.

$$
i_{c}=\frac{G_{s}-1}{1+e}\left(\cos \theta-\frac{\sin \theta}{f_{r}}\right)
$$

ここで, $W^{\prime}=\gamma_{w} V\left(G_{\mathrm{s}}-1\right), G_{s}=\gamma_{s} / \gamma_{w}, \gamma_{s}:$ 被覆ブロックの 単位体積重量である.

\section{（3）表層すべりに対する安定性の評価}

被覆ブロックの安定性を評価するため，マウンド表面 の動水勾配 $i$ と限界動水勾配 $i_{c}$ の比 $i_{c} / i$ をとり安全率と した．安全率が 1 以下だと被覆ブロックは不安定と評価 される. 図-10 に case1 の, 図-11 に case3 の表層すべり に対する安全率を示す，各図では上段に示すマウンド断 面図中にプロットされた赤点位置における安全率を下段 のグラフで示しており, さらに安全率は水位差 $40 \mathrm{~mm}$, $80 \mathrm{~mm}, 120 \mathrm{~mm}$ に対するものを表している.いずれのケ 一スにおいても水位差が増加寸るにつれて安全率は低下 していることがわかる.

また，マウンド下部よりも法肩部の方が安全率は低下 した. これはマウンド上部の方が動水距離は短く，被覆 ブロックに作用する浸透力が大きくなるためと考えられ る. 実験において実際に浸透流により被害のあったCase1 では, 図-10 に示すように水位差が $120 \mathrm{~mm}$ の場合には安 全率 1 を下回るのに対して，実験では浸透流による被害 がなかった Case3 の被覆ブロックに対しては安全率 1 を すべて上回っている. このように，本研究で提案する評 価手法によるブロック被災の安全率の評価結果が実験結 果と概ね一致していることが確認された.

\section{6. まとめ}

本研究では，浸透流を考慮した式から適当な被覆ブロ ックの形状を推定した。 さらに作成した模型被覆ブロッ クで，防波堤に来襲する津波を模擬した水理模型実験を 行い被覆ブロックの被害を調べた。本研究によって得ら れた結果を以下に示寸。

1)間隙のある被覆ブロックは浸透流による被害が抑 えられた。

2）脚のある被覆ブロックは浸透流による滑り落ちる ような移動が抑えられた。

3) Case3 について水位差 $135 \mathrm{~mm}$ での安定重量を算出 し，最適形状として実験を行ったところ，水位差 130mm まで被害は抑えられたが，それ以上だと被 害が発生したため，算出方法に改良の余地がある.

4) 被覆ブロックの水位差による浸透流に対する安全 率を求めて評価し，実験結果と概ね一致した。

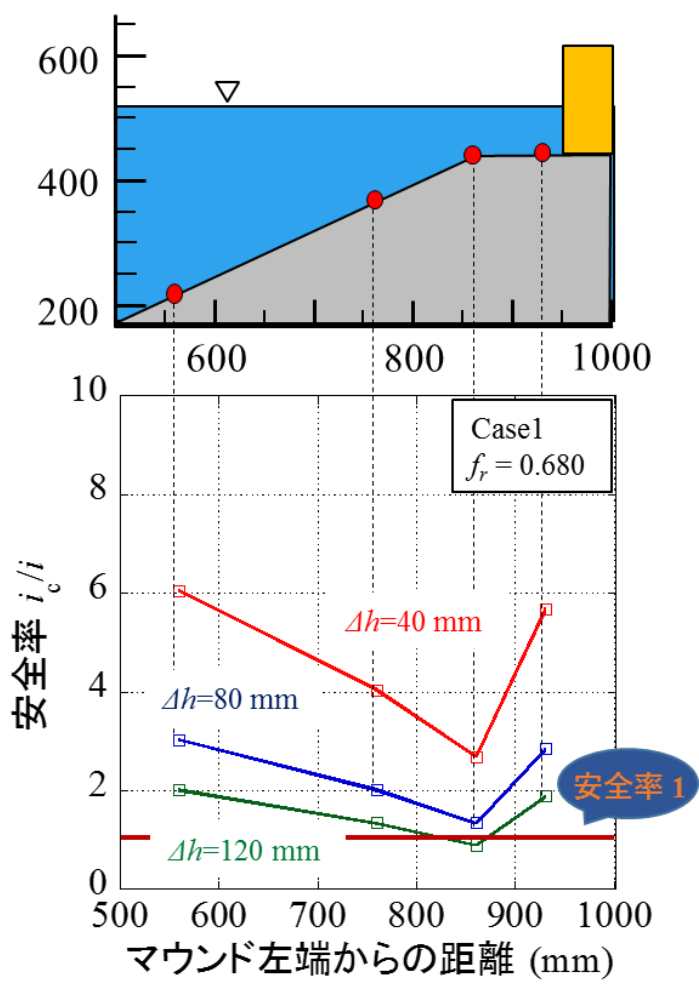

図-10 case1 の表層すべりに対する安全率 $i_{c} / i$

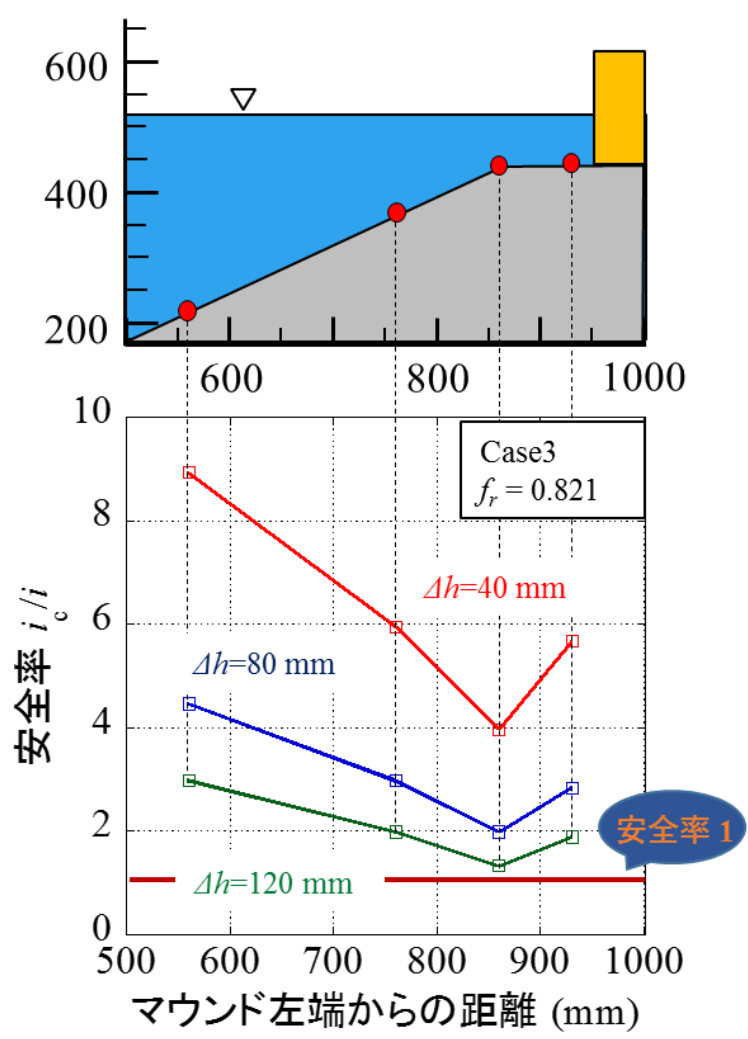

図-11 case3 の表層すべりに対する安全率 $i_{c} / i$

謝辞 : 本研究は科学研究費補助金基盤研究(B) : 研究課題 25289149「浚渫土防㷋ブロックを活用した新形式津波防 波堤の開発研究」(研究代表者: 笠間清伸) の成果の一部 である.また，本研究は，一般財団法人港湾空港総合技 術センターの研究開発助成を受けたことを記して, 謝意 を表したい. 


\section{参考文献}

1） 谷本勝利, 柳生忠彦, 村永努, 柴田銅三, 合田良実:不規則 波実験による混成堤マウンド被覆材の安定性に関する実 験, 港湾技術研究所報告, vol.21, No.3, pp.3 42, 1982.9.

2) 大井邦昭, 林健二郎, 河野茂樹 : 津波越流に対する海岸堤 防及び防波堤の強化に関する実験的研究.

3) 近藤圭央, 有川太郎, 関克己, 村川はるみ: 3 次元数值波動 水路を用いた防波堤頭部の被覆材移動による被災の検討, 土木学会論文集 B2 (海岸工学), vol.B2-65, No.1, 2009.
4) 井上翔太, 笠間清伸, 善功企 : 越流・浸透流を考慮した捨 石マウンドの安定重量に関する水理模型実験, 土木学会 論文集 B3 (海洋開発), Vol.71 No.2,pp.I_1059-I_1064, 2015.

5) 榊山勉, 鹿島遼一: 消波ブロックに作用する波力に関する 実験スケール効果, 電力中央研究所報告・研究報告, U89024, 1989.10.

6) 水谷法美, 中村友昭, 土井勇人 : 密度を考慮した消波ブロ ックの耐津波安定性評価手法に関する研究, 土木学会論 文集 B2 (海岸工学), Vol.71, No.2, pp.I_907-I_912,2015.

(2018.2.8 受付)

\title{
A HYDRAULIC MODEL EXPETIMENTS FOR THE DIMENSION OF ARMOR BLOCKS UNDER OVERFLOW AND SEEPAGE FLOW ACTION
}

\author{
Shuhei TAKESHITA, Kiyonobu KASAMA, Yasuyuki NAKAGAWA, \\ Kouki ZEN, Zentaro FURUKAWA and Yuichi YAHIRO
}

In order to improve the stability of breakwater due to tsunami-induced overflow and seepage flow, it is effective that putting armor blocks on the harbor-side mound of breakwater. Therefore, the optimum shape was derived using the stable weight calculation equation of armor block considering seepage flow proposed by our research group. Also, a hydraulic model experiment for the model of Kamaishi Bay breakwaters under tsunami condition was conducted to evaluate the extent of armor block damage. As the result from this study, following conclusions were obtained. Damage due to seepage flow was suppressed in the armor blocks with gaps. The armor blocks with legs was restrained from sliding down due to seepage flow. The armor blocks calculated as the optimum shape was damaged earlier than planned. Therefore, improvement is necessary. Stability ratio against surface slip was evaluated and it agreed roughly with the experimental result. 